\title{
ФИЛОСОФИЯ КУЛЬТУРЫ
}

\author{
Т.С. Лапина
}

\section{ИДЕНТИФИКАЦИЯ КУЛЬТУРЫ: ФИЛОСОФСКИЕ КРИТЕРИИ}

\begin{abstract}
Аннотация. В статье выявлены детерминанты проблемной ситуации вокруг темы: разноречивость в понимании культуры; недостаточная разработанность категориального аппарата философской рефлексии над культурой; невыявленность закономерностей ее складывания, потребность в уточнении соотношения понятий «цивилизация» и «культура», в углублении ее аксиологического понимания; далекое от удовлетворительного состояние исследование влияния на культуру общественных практик, в частности - социальных (в узком смысле слова). В качестве ответа на выявленные проблемы автор отвечает на вопрос, что выдвигает философия культуры: идею или утопию последней? В русле аксиологического понимания культура рассматривается в качестве производства и освоения ценностей, позитивного достояния человечества, трудными путями им и создаваемого. Нравственная идея истинной человечности полагается в статье в качестве верховной «правительницы» культуры. Дается определение предмета философии культуры, в полемике с некоторыми исследователями раскрываются ее философские основания, инварианты и универсалии. Освещен такой малоизученный вид культуры, как социальная, охарактеризованы основные черты антикультуры. В качестве главного вклада философии в культурологию расцениваются выведение базовых принципов объяснения и производства культуры, экспликация ее закономерностей, перечень которых предполагается автором.
\end{abstract}

Ключевъе слова: культура, окультуренность, ценность, духовность, философия культуры, основания, универсалии, инварианты, закономерности культуры, человек.

\section{Проблемная ситуация вокруг темы}

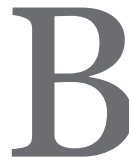

связи с происходящими серьезными изменениями внутри стран и на международной арене субъектам надо решать, что в сфере общественного бытия отстаивать и строить, с одной стороны, что подсекать и устранять - с другой. И сохранение чего-то от прошлого, и создание нового, и неантизация вредного должны осуществляться как культуроносные акции, ибо именно в культуре как производстве и освоении ценностей людьми аккумулируется позитивное достояние человечества. Но вокруг ее толкования столетиями ведутся споры, при этом в попытке их разрешить некоторые философы и культурологи обращаются и к потенциалу теоретического любомудрия. Философский подход к осмыслению объекта предполагает в числе прочего анализ последнего на уровне диалектической категории общего, поэтому резонно прояснить содержание таких понятий, как основания, инва- рианты, универсалии культуры, которые входят в категориальный аппарат философской рефлексии над культурой. Необходимо также выявление закономерностей её складывания и функционирования, без чего философия культуры не может заиметь статуса относительно самостоятельной социо-гуманитарной дисциплины.

Рассматривая в общих чертах отношение человека к сущему и выявляя направления развития человека и социума, философы полагают, что наиболее продуктивная позиция субъектов по отношению к сущему и к ним самим состоит в творении ими культуры. Но и цивилизация создается людьми, поэтому разработка общего понимания культуры запрашивает выяснения её соотношения с цивилизацией, которое, как известно, разные исследователи трактуют разноречиво. На наш взгляд, цивилизация как надбиологическо-человеческая форма сущего - это всё устройство сложно и во многом искусственно организованного - 8 отличие от нецивилизованного - общества: его 


\section{Философия и культура 10(70) • 2013}

атрибутом является такая комплексная структура, как государство. Современная наиболее развитая цивилизация предполагает демократию, правовое и социальное государство. Цивилизованное общество структурировано на подсистемы общественной жизнедеятельности (экономическую, социальную, политическую, духовную), на сословия, социальные классы и слои, а в пространстве подсистем формируются соответствующие им виды субъектов и субъектных структур, благодаря усилиям которых функционируют эти подсистемы. Средствами права, религии, нравственности, а нередко и военизированными путями в обществе достигается упорядоченность того или иного рода, но только в основном: присутствия хаоса и стихийности в той или иной мере, наличия каких-то неустоявшихся и переходных форм ни одна цивилизация не избегает. В условиях последней социальные связи начинают довлеть над естественными, что сопряжено с утверждением оседлости, появлением долговременных поселений, а среди них - городов, и что невозможно без возникновения писаного права, которое как нечто общеобязательное стягивает общество.

Цивилизация, с точки зрения общечеловеческих интересов, включает в себя переплетение положительного и отрицательного, культуры и антикультуры, некоторые неокультуренные формы, например, в неё может входить «дикий базар», а не только организованный маркетинг. Культура складывается в рамках цивилизации (при этом отдельные культуроносные веяния, нередко воспринимаемые в качестве контркультуры, могут быть прологом к будущей цивилизации) как то, что цеенностно ${ }^{1}$, а потому становится объектом бережного отношения, воспроизведения (если оно возможно в принципе), нередко почитания и выразительного семиотического оформления.

В основных тенденциях культура, как нам доводилось показывать, созидательна и гуманистичн ${ }^{2}$, что, однако, лишь постепенно выявилось и продолжает выявляться по ходу общественной истории. А.Н. Чумаков отмечает «важность подчеркивания» того, что «большинство исследователей соотносят с понятием «культура» не любую человеческую деятельность..., а только те его

\footnotetext{
1 «В каждой культуре, - пишет П.С. Гуревич, - обнаруживается ее ценностная природа, то есть наличие в ней стойких ценностных ориентаций». (Гуревич П.С. Философия культуры. М., 1995. С. 199).

2 См.: Лапина Т.С. Философское обоснование общего понимания культуры // Вопросы культурологии. 2008. № 2.
}

(человека - Т.Л.) усилия, которые содействуют развитию человека, направлены на удовлетворение его материальных и духовных потребностей..., возвышают его... Культура во всех своих формах и проявлениях обладает позитивной ценностью...»³. Если люди добиваются превалирования в условиях общественного бытия культурогенной активности над активностью разрушительной, человек как родовое существо обретает статус созидателя, а такой статус носит долженствующцй характер, ибо выполнение субъектами адаптирующей и творческой роли позволяет в общем и целом обеспечивать условия для выживания и развития людей.

Культура, конечно, в первую очередь, формируется субъектами, создающими артефакты, но в её творении обязательно участвуют также авторы правильных социальных оценок, т.е. те субъекты, которые духовно, аксиологически осваивают произведенное, содеянное и намечаемое людьми, среди чего требуется выделять как антиценности, так и ценностные создания. Значит, желательно эксплицировать трудности и проблемы, стоящие на пути идентификации ценностей, обнаружить противоречия, без смягчения которых не продуцируются определенные ценности, например, социальная защита, высокий уровень образования. Н.А. Бердяев писал: «Бога, как и человека и мир, нельзя иначе понять как через оценку, оценка же есть творческая активность» ${ }^{4}$. Ценность - дитя своеобразного союза между создателем артефактов и реципиентом-потребителем сотворенного, хотя оба они могут совпадать в одном лице. Культуроносный опыт утверждается и «языком» человеческого признания, уже поэтому культура объективно-субъективна, а изъятие оценочно-аксиологической стороны из состава культуры ведет к её излишней объективации.

Предостерегая от упрощенного подхода к аксиологическому пониманию культуры, хочется подчеркнуть: культура есть её непрерывное становление и освоение, а не механическая сумма достижений. При этом «ценности, которые конституируют культуру, - подчеркивает П.С. Гуревич, - рождаются из недр человеческого бытия ${ }^{5}$ в качестве «не только «осознанного», но и жизненно, экзистенциально прочувствованного бытия» 6 .

\footnotetext{
3 Чумаков А.Н. Метафизика глобализации. Культурно-цивилизационный контекст. М., 2006. С. 88.

${ }^{4}$ Бердяев А.Н. О назначении человека. М., 1993. С. 261.

5 Гуревич П.С. Философия культуры. М., 1995. С. 286.

6 Там же. С. 119.
} 


\section{Философия культуры}

Ценностный отбор, идентификация ценностей на протяжении общественной истории носят сложный и противоречивый характер и составляют относительно самостоятельное направление духовного производства, результаты которого кристаллизуются в ходе диалогов, полилогов, более или менее острых, а порой ожесточенных споров, столкновений и социальной борьбы между сторонниками различных ценностных установок. На путях утверждения ценностей полегло немало человеческих жертв, спорадически происходят переоценки - девальвации и ревальвации - ценностей. Они вынашиваются в ходе накопления массами социально-экзистенциального опыта. Некоторые из ценностей бывают выстраданы, так, права человека выковались в горниле испытаний и страданий, навлекаемых на людей деспотическими режимами, войнами, эксплуатацией, бесправием, дискриминацией, социальными раздорами, преступностью, бедностью, нищетой.

Кто-то скажет, что подобные рассуждения ведутся с точки зрения идеи, но разве так не должно быть? В.М. Межуев обоснованно пишет, что «всё, к чему философия имеет отношение, получает в ней форму идеи, становится идеей»7. Метод идеализации ни в философии, ни в науке ещё никто не отменял. Имеется кроме того мнение, будто философы выстраивают утопии для культуры ${ }^{8}$. Спрашивается, что же предлагает философия культуры: идею или утопии последней? А может быть указанные сущности нельзя рассматривать в исключающее-разделительном смысле? Пытаясь ответить на заданные вопросы, учтём, что через всю мировую философию проходит принции платонизма в той или иной модификации. В виде целеполагания, составления проектов, программ, наметки планов, выдвижения идей, вынашивания идеалов, выработки регулятивов люди обычно предпосылают идеальное реальному в качестве предела производства объекта. Но и утопии выстраиваются некоторыми мыслителями, в Европе это происходило начиная с модели идеального государства самого Платона. А, например, проект создания Царства Божия на Земле на основе реализации Всеединства - в виде Богочеловечества и Богоматерии - оказался той утопией, которую лелеял Вл. Соловьев и от

\footnotetext{
${ }^{7}$ Межуев В.М. Идея культуры. Очерки по философии культуры. М., 2006. С. 5.

8 См.: Гусейнов А.А. Философия как утопия для культуры // Вестник Российского философского общества. 2007. № 4.
}

которой, как якобы осуществимой в посюсторонней жизни, он с горечью отказался в последние два года своего творчества.

Здравые идеи продуктивны в отличие от утопий. Вместе с тем, нельзя не признать, что в идеях нередко присутствует что-то от утопий, поскольку идеи не осуществимы в полном виде, т.е. связь между понятиями «идея» и «утопия» носить соединительно-разделительный характер. Желательно из идей выбрасывать утопические элементы, в то время как в утопиях усматривать зародыши здравых идей и стремиться их воплощать. Идея гуманизма - одного из важнейших признаков, наличие которых в человеческих деяниях позволяет считать их культуроносными, - реализуется, правда, чаще всего трудными путями, неполно и противоречиво. Но, значит, гуманизм - не утопия. Приведем лишь немногие иллюстрации из длинного ряда к этому: социальное обеспечение граждан в цивилизованных странах, международная защита прав человека, удававшееся предотвращение некоторых военных агрессий на основе норм международного права, профилактика геноцида, апартеида, дискриминации на этой же основе, деятельность выдающихся гуманистов - доктора Ф. Гааза, Альберта Швейцера, Дж. Неру, матери Терезы, правозащитника С.А. Ковалева и многих других.

Вся общественная история свидетельствует о том, что люди весьма часто выступают не в качестве созидателей, а как разрушители, под угрозу они поставили условия своего бытия. Человек как родовое существо в его сущности (достоинстве) есть синтез таких качеств, как биологичность, социальность, деятельностное начало, разумность, духовность, психологизированность, индивидуализированность. Эта сущность противоречива, ибо противоречиво уже основополагающее в определении роли человека в мироздании деятельностное начало: оно может проявляться в активности как адаптирующее-созидательного, так и деструктивного характера по отношению к природе, социальной среде, субъектным структурам и человеческим индивидам. Когда субъекты обеспечивают преобладание в их активности созидательности по сравнению с контрпродуктивностью, тогда это влечет пролиферацию сущего - его прирастание ноосферой.

Слабо пока исследована реализация окультуренности посредством общественных практик: антропо- и обществофильных. Среди них особо большое значение в настоящее время приобретают 


\section{Философия и культура 10(70) • 2013}

гуманные социальные практики. Это соблюдение прав человека, прав работника и прав работодателя, прав ребёнка, создание государством условий для законопослушного бизнеса, социальное обеспечение и защита, социальная работа, доступное здравоохранение, расширение доступа к образованию и духовным ценностям, благотворительность, оказание гуманитарной помощи, внедрение биоэтики, создание служб доверия и спасения и т.п. Гуманным («светльм») практикам противостоят антигуманные («темные» и «чёрные») практики: рабство; эксплуатация человека человеком; геноцид; апартеид; дискриминация по полу, вероисповеданию, национальной принадлежности, политическим позициям, мировоззрению; применение детского труда; отношение к живой военной силе как к «пушечному мясу»; пытки; дедовщина; преступность; дикие расправы над неугодными и др. Свертывание и искоренение на Земле зловещих, инфернальных практик и - наоборот - развертывание практик гуманных входит в основные направления современного окультуривания человечества. Разработка и применение специальных методов, технологий гуманизации жизни общества и поддержки его человеческого потенциала составляет социальную культуру ${ }^{9}$, которая пока теоретически заметно слабее раскрыта по сравнению с духовной и материальной культурами.

Недостаточно показано в культурологической литературе, что на сложностях складывания культуры могут отражаться трудности становления субъектов производства и освоения ценностей, препятствием чему бывают экономически и политически угнетенное положение личности, недостатки образования и воспитания, задавленность масс нищетой и т.д. На перипетиях вызревания культуроносного достояния сказывается извечная борьба между созидательной и разрушительной человеческой активностью, в качестве одного из отрицательных исходов которой актуально раскрыть утверждение на длительный исторический срок мнимых ценностей в виде, например, почитания населением диктатора. Обманчивым светом мнимых ценностей бывают заворожены массы, что мешает утверждению подлинной культуры в областях политики, экономики, права, воспитания, в художественной сфере и т.д., за примерами чего россиянам недалеко ходить.

\footnotetext{
9 См.: Лапина Т.С. Социальная культура как атрибут современной цивилизации // Вопросы культурологии. 2010. № 8.
}

Основания культуръ. Метафизическая рефлексия над объектом, в первую очередь, согласно Аристотелю, обращена к его началам и истокам. В центре метафизики культуры находятся, с одной стороны, изначальные детерминанты культуры, с другой - явления и процессы, которые она сама детерминирует, т.е. устойчивые и в этом смысле - конечные следствия её функционирования, выступающие её самодетерминантами. Некоторые исследователи полагают, будто в качестве культурогенных оснований следует рассматривать компоненты самой философии: философские категории. Но позвольте привести более широкую интерпретацию культурогенных оснований и отнести к ним заключенные в логике общественной истории зависимости общего и необходимого характера между человеком и обществом, человеком и природой, обществом и природой, между социальными объединениями, человеческими индивидами. Поддержка и наполнение таких зависимостей по преимуществу культурогенной деятельностью влечет выживание и развитие человечества. Подобные связи выявляются и семантизируются философией, что же касается её категорий, то они входят в такой вид оснований, как гносеологические.

Приведенная интерпретация общих детерминант культуры позволяет понять, откуда она 8 философско-логическом (в отличие от конкретно-исторического) плане проистекает, почему составляет необходимость в развивающемся обществе и что находится среди определителей её эволюции. Соответственно традиционным разделам философии выделяются онтологические, гносеологические, Философско-антропологические, социально-философские и аксиологические культурогенные основания. Выявляя изначальные причины и конечные следствия существования культуры, философия репрезентирует базовые принципы её объяснения. Но любомудрие не просто повествовательно, а и продуктивно, философы разрабатывают также базовые принципы преобразования окружающего с целью создания и воссоздания очеловеченного мира. Объяснительные положения либо являются также принципами производства культуры, либо тесно сопряжены с последними. Главное в философии культуры - это выведение базовых принципов её производства.

Онтологические основания. Сущее - это беспредельная сфера действия таких контрарных 


\section{Философия культуры}

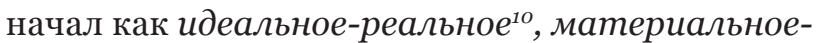
процес-суальное, упорядоченное-хаотичное. Культура развертывается в социальном пространстве преодоления субъектами противоречий между идеальным (общественные цели и задачи, программы, проекты, идеалы, замыслы) и реальным (содеянное и достигнутое людьми, общественные события и условия, состояние общества, поведение и деятельность участников общественной жизни), что составляет один из принципов объяснения культуры. А умение субъектов обеспечивать взаимокорректировку и взаимообогащение идеального и реального предстает одним из принципов её производства. Культура основана и на способности субъектов получать новые духовные, социальные, второприродные формы, представляющие собой ценность, при этом формообразующий процесс - это культурогенная активность субъектов. Принципом объяснения выступает осознание появления культуроносных созданий как итога специфической обработки материала и/или особого возделывания культурной предметности на определенном субстрате. Соответствующий принцип производства культуры заключается в необходимости адекватно определять или же искусственно создавать материю возделывания, к тому же овладевать различными видами деятельности.

Что же касается оппозиции хаос-упорядоченность, то отметим: одно из свойств культурогенной активности заключается в упорядочивании бытия, обеспечении перехода от хаоса к системной организованности (в областях хозяйственной, управленческой, образовательной и иной общественной жизнедеятельности), создании все более продуктивных экономических, политических, правовых, информационных, образовательных, научных, здравоохранительных, социально-обеспечительных, художественных, спортивных и иных структур.

Гносеологические основания. Культура основана и на постижении сущего. Совокупность знаний, добытых человечеством, оперирование положениями всех видов наук, достижение понимания окружающего и происходящего представляют собой мощные «плиты», лежащие в фундаменте производства и освоения культуры. В процессах

\footnotetext{
10 Мы исходим из программно-генетической парадигмы сущего, присоединяясь к мнению некоторых ученых о том, что сингулярность представляла собой сверхген, в котором была заложена развертывающаяся уже на протяжении 14,5 миллиардов лет программа эволюции Вселенной.
}

идентификации ценностей тоже участвуют знания, но решающая роль в установлении ценностей принадлежит видам собственно духовной (если отличать её от теоретической) культуры: философии, морали, искусству, религии. Духовность означает признание и почитание святынь, верность им. В индивидуально-личностном преломлении духовность увязана с соотнесением личностью того, что она делает, думает, намеревается совершить, с идеалами гуманности, добра, светской и/или религиозной святости, с вызреванием в её душе чувства ответственности за свои деяния. В социальном преломлении духовность заключается в кристаллизации представлений о правильном, должном, о высших ценностях в общественном сознании, признании необходимости социальными средствами содействовать утверждению достоинства человеческого индивида, наложении на субъектов ответственности за состояние общества и положение в нем личности.

Формирование культуры предполагает органичное включение духовности в такие средства постижения сущего, как оценка, интерпретация, установление значений, смыслозадавание и смыслосчитывание, вчувствование и переживание, вследствие чего складываются семантические репрезентации. В основания культуры входят поиск истинного, определение правильного, задействованность эстетического воображения. А познавательные принципы её производства заключаются в непрестанной постановке и улавливании проблем развития различных сфер общественной жизнедеятельности, проектировании новых общественных объектов, которые носили бы культуроносный характер, практической реализации правильного, эстетизации общественной среды по законам красоты. Культура, таким образом, обусловлена природой сознания не только как отражения, но и как идеального создания действительности.

Философско-антропологические основания. Окультуривание общественной жизнедеятельности детерминировано и родовой природой людей, а также философским пониманием человека, которое со временем углубляется. П.С. Гуревич первичным основанием культуры обосновано считает «антропологические данности», а именно «неукорененность человека в природе, потребность человека в реализации тех побуждений, которые не являются инстинктивными. Культура в этом смысле выступает как продукт открытости человеческой природы (курсив 


\section{Философия и культура 10(70) • 2013}

П.С. Гуревича. - Т.Л.), не имеющей окончательной фиксированности» ${ }^{11}$. И действительно, складывание культуры объясняется уже узостью внешних пределов существования, природной хрупкостью и постоянной незавершенностью человека как родового существа. Отсюда выводимы такие из числа принципов объяснения и производства культуры, как нужда людей в создании собственной духовной, а также второприродной, социальной и домашне-бытовой среды, самосоздавание.

Культура приурочена к полу, возрасту, занятиям людей, характеру их коммуникаций с «другими», национальности личностей, обусловлена в числе прочего степенью освоения индивидами социального опыта и необходимостью для них социализовываться. Она содержательно детерминирована и тем, что люди силами труда и творчества в непрестанно меняющихся условиях должны цивилизованным образом удовлетворять свои многообразные, со временем возвышающиеся разумные запросы, воспроизводить самих себя. Универсальныйхарактер освоения людьми мира, их нужда в многостороннем жизнеустройстве обусловливают становление культуры. В веере рассматриваемых детерминант находится также создаваемый моралью образ человека, каким он должен быть. Однако нельзя произвести полного «вычитывания» культуры из родовой природы человека и общества, в конкретных модификациях культура может быть весьма неожиданной, ибо она - плод и человеческого творчества, кроме того она зависит от своеобразия конкретных условий жизнедеятельности людей (например, от географической среды, традиций, своеобразия истории страны).

Человек и жизнь как «меры всех вещей»это общий принцип, задающий культуроносный характер определенным формам общественного бытия, так как окультуривание требует от людей возделанности создаваемой ими среды согласно «человеческому измерению» - позитивным запросам субъектов. Возделанность достигается лишь в относительной мере и реализуется в ходе длительных, сложных и противоречивых общественно-исторических процессов. Но человеческой натуре присущи и негативные свойства, кроме того почти за любой активностью людей наступают и вредные последствия, бурно в настоящее время нарастающие, из чего вытекает актуальность дальнейшей разработки и внедрения технологий

${ }^{11}$ Гуревич П.С. Философия культуры. М., 1995. С. 33-34. страховочного и защитного типов, насущность совершенствования педагогических и криминологических методик блокирования дурного человеческого поведения.

На основе субстанциальности проживания человеком жизни как жителем в цивилизованных странах предусматривается антропофилизация социальности: разработка государственных курсов гуманной социальной политики, улучшение условий труда, создание новых рабочих мест, профилактика социальных конфликтов, оказание населению гуманитарной помощи тогда, когда природные, социальные или техногенные бедствия повлекли катастрофические последствия, другие меры по поддержке человеческого потенциала. Coответственно прилагаются общественные усилия по приданию гуманистической ориентированности экономике, политике, законодательству, системе образования, ведется государственный и общественный контроль над качеством жизни и демографическим состоянием населения.

Появились находки в изыскании новых путей согласования природного и социального начал человеческой натуры. Так, в цивилизованных странах стала лучше учитываться возрастная и половая дифференциация населения в областях трудовой занятости, образования и обучения, торговли, медицины, туризма, развиваются биоэтика и геронтология как теории и практики. Контрактная модель врачевания, эвтаназия (пока в нескольких странах), трансплантация человеческих органов и тканей, инкорпоральное зачатие, генетическая экспертиза и другие формы биомедицинского обслуживания практикуются при учёте не только медико-биологичекого состояния пациентов, но также их вероисповедальных и гендерных запросов. Экономической и демографической теориями выработаны критерии положения индивидов в обществе: прожиточный минимум, потребительская корзина, черта бедности, децильный коэффициент и др., а получаемые с их помощью данные используются при разработке социальных программ.

Разумеется, социальное обеспечение и защита, социальные программы заметно свертываются во время экономических и политических кризисов, но как уже ранее практикуемые формы они вошли в гуманистическое достояние человечества и возрождаются, неизбежно в чем-то подвергаясь корректировке, после выхода стран из кризисного состояния.

Итак, в духовное содержание современной цивилизации входит осознание необходимости 


\section{Философия культуры}

продуцирования социальных, правовых, биоэтических, пропагандистских средств утверждения личностной автономии и достоинства, т.е. окультуривания особого рода, недостижимого прибеганием к ресурсам лишь экономического и технического характера. Нельзя не признать, если брать за точку отсчета международную юридизацию прав человека в середине XX в., что человечество сильно продвинулось вперед в изобретении и реализации социальных форм гуманизма. И хотя издержки человеческого активизма очень велики, а проблем в области окультуривания человечества больше, чем достижений, тем не менее, можно говорить о наличии такого следствия функционирования культуры, как воспроизводство и развитие личности в качестве субъекта труда, творчества, познания, общения.

Социально-философские основания. Культура не только антропологична, но и общественна, и одним из её оснований является общество в качестве ее субстрата. Другой социально-философский объяснительный принцип заключается в признании творимости общества в определенной мере, оно обладает естественно-искусственной природой, его искусственность с ходом истории возрастает, в чем велика роль активности субъектов. Общество, таким образом, - и субстрат, и частично - творение культуры.

Общественный детерминизм носит объективно-субъективный характер, и более всего в его субъективной стороне выражается зависимость протекания общественной жизнедеятельности от природы, уровня развития, характера поведения и деятельности субъектов производства, управления, познания, труда, творчества, политических движений, гражданских инициатив. В качестве ведущих социальных субъектов могут выступать и видные человеческие индивиды, и определенные субъектные структуры. Субъект - создатель артефактов, но и сам в некотором смысле артефакт, его становление обусловлено его активностью, при этом усложняющейся по мере общественного развития, так как оно сопровождается возрастанием диверсификации и интенсификацией человеческой деятельности.

Общество - социальная среда производства и воспроизводства человека, но оно имеет и собственные существенные характеристики, ему присущи и надындивидуальные реалии. ${ }^{12}$ Поэтому

12 См. об этом: Момджян К.Х. Социальная философия. М., 1997. C. 287, 296-297. не только активность и запросы индивидов, но и потребности общественного организма, а также земного социума в целом составляют основание развития и функционирования культуры. Она направлена на сохранение общественных устоев и констант -экологических, экономических, демографических, организационных и иных, а кроме того - на создание новых форм общественной жизнедеятельности, чтобы общественный организм мог отвечать на вызовы времени. Комплекс социальных гарантий должен включать в себя средства своеобразного обеспечения и защиты не только личности, но и цивилизованного общества, должна преследоваться и такая цель, как достижение общего блага, которое выразительно определил В.С. Нерсесянц: «общее благо - это не отрицание различий интересов, притязаний, воль, целей и т.д. отдельных субъектов, а общее условие их возможности» ${ }^{13}$.

Аксиологчческие основания культуры заключаются в необходимости выведения субъектами оценок деятелей и реципиентов-потребителей, а также происходящего, созданного, содеянного, в выявлении позитивных накоплений среди произведенного людьми, экспликации кроме того вредоносных результатов человеческой активности. В условиях ускоренности и обостренной проблематики современного общественного развития особенно важно опережающим образом устанавливать то, что действительно явится благом из ряда намечаемых мер, нововведений и преобразований. Это объяснительные принципы аксиологической трактовки культуры, из которых вытекают её продуцирующие принципы. А именно: ценности составляют опоры для субъектов в их активности, преломляясь в руководства к ней. Поэтому ценностный отбор выступает одним из мирных способов социального утверждения, с одной стороны, и социального отвержения - c другой, т.е. входит в механизмы общественной динамики. Доброкачественный ценностный отбор предполагает правильность и своевременность оценок, он неотторжим от способности субъекта бороться за отстаивание адекватной характеристики артефактов и определенной человеческой активности. В аксиологические принципы культурогенного производства входят и умение дорожить ценностями, полагать утверждающее, корректирующее, социально-очищающее значение оценок в качестве детерминант поведения. В современной

${ }^{13}$ Нерсесянц В.С. Философия права. М., 1999. С. 70. 


\section{Философия и культура 10(70) • 2013}

нравственной философии идея общечеловеческих ценностей составляет момент, направляющий ценностный отбор.

Инварианты кулътуръ. К инвариантам культуры относятся возделанность, созидательность, гуманистичность, ценностность, одухотворенность, программность, регулятивность, семантичность и семиотичность, проблемность и проблематичность, «родовитость». Культура созидательна как наращивание сущего ноосферой, возделывание благ, горнило формирования личностей и субъектных структур. Трудно, но непременно на Земле продвигается гуманизация с ходом истории трудовых, политических, правовых, межнациональных отношений, медленно, но верно повышается качество жизни населения, хотя далеко не полно и не повсеместно, но все же имеет место соблюдение прав человека.

Понимание культуры должно быть более сложным, чем сведение её к общественно-исторической фактичности уже потому, что такое сведение не позволяет отделить культуру от её антиподов. На основе накопления социальноэкзистенциального опыта проживания людьми жизни создания культуры предстают в «ореоле» довольно высоких оценок и обретают статус компонентов общественного достояния. На наш взгляд, обладающие качественностью артефакты и человеческая деятельность, по каким-либо причинам не возведенные в общественном сознании в ценность, лишь потенциально относятся к культурному достоянию. Вся культура одухотворена ценностным отношением субъектов к её созданиям и создателям, и вне одухотворенности культура не актуализируется ${ }^{14}$.

А программность культуры заключается в закладывании в её проявления программ и/или образцов, социокодов. В.С. Степин считает программность определяющим признаком культуры, он пишет о возможности её рассмотрения «как системы информационных кодов, закрепляющих исторически накапливаемый социальный опыт, который выступает по отношению к различным видам деятельности, поведения и общения... как их надбиологические программы» ${ }^{15}$. Отсюда вытекает

14 Так, великие произведения И.-С. Баха публика во времена их создания не принимала, и только век спустя творения Баха были поняты и стали восторженно приниматься слушателями, вошли, значит, в актуальное музыкальное достояние.

15 Степин В.С. Культура // Вопросы философии. 1999. № 8. C. 63. регулятивность культуры: принятые программы склоняют или обязывают их составителей и адресатов к активности определенного рода. Более конкретно предписывающе-моделирующую роль выполняют обязывания, запреты, дозволения.

Не все исследователи ставят отнесение предписаний к культуре в зависимость от их содержания. А.Я. Флиер тесно увязывает окультуренность со следованием твердо установленным предписаниям, отвлекаясь от вопроса об их социально содержательной наполненности. Названный автор пишет, что «поступать культурно - это поступать в соответствии с действующими правилами...», что «культурное - это есть упорядоченное в соответствии с общепринятыми нормами» ${ }^{16}$. Спрашивается, а если это нормы из арсенала фашистских предписаний, обязанность всеобщего доносительства, например? Согласно цитируемому автору, «вся культура - это форма разделения человечества на конкретно-исторические сообщества и формирования локальных комплексов правил поведения и суждений, основанных на социальном опыте каждого сообщества» ${ }^{17}$. Но сообщество, скажем, талибов, конечно, вырабатывает правила поведения для своих членов, эти правила являются антигуманными по отношению к представителям других сообществ. Думается, называемое А.Я. Флиером культурой всецело относится к цивилизации, но далеко не всегда достойно считаться культурой.

В ряд культуроносных инвариантов входят семантизация и семиотизация, выступающие необходимыми способами репрезентации и утверждения культуры. Однако широко по социальным и гносеологическим причинам может практиковаться и смыслознаковая антикультура, иначе говоря, симулякризация: неадекватность приданных смыслов и обозначений объектам смыслозадавания. Например, социально низменное и черное выдается за высокое и достойное с помощью применения знаков возвеличения или эстетизации (так, иногда романтизируются образ жизни и личности криминальных авторитетов), и наоборот - положительное и высокое может выдаваться за нечто недостойное и преступное, будучи маркированным знаками дискредитации, что особенно усиленно практикуется в периоды

\footnotetext{
16 Флиер А.Я. Перспективы культурологии в исследовании социальных функций культуры // Вопросы культурологии. 2009. № 5. C. 46.

17 Там же. С. 47.
} 


\section{Философия культуры}

массовых необоснованных репрессий. Симулякризация требует развенчания с целью установления правды и справедливости.

Проблемность культуры коренится в стремлении субъектов найти достойный ответ на возникающие в обществе проблемы: управленческие, экономические, образовательные, демографические и иные. Культуроносна даже постановка реальных проблем уже потому, что без выявления их невозможно изыскание путей общественного развития. Проблематичность культуры выражается в далеком от фатальности характере её утверждения, перебивке её функционирования временами декультуризациии то в одном, то в другом регионе, в остроте глобально стоящего вопроса о том выживет ли она. Культура проблематична и в силу постоянной незавершенности её выявленности, ибо в общественной истории не совсем редки периоды размывания и переоценок ценностей. Конечно, имеются непреходящие ценности: изобретения, произведения высокого искусства, научные открытия, гуманное общественное служение, подвиги, совершенные ради достижения истины и утверждения добра, аксиомы права и др. Но и «вечные» ценности не утверждаются самостийно, каждый раз они должны осваиваться новыми поколениями, что, в частности, требует хорошей постановки воспитания в семьях и образования в учебных заведениях, налаживание чего весьма далеко от совершенства. На примере России мы видим, что вокруг содержательной и методической сторон воспитания и образования специалистами ведутся острые, не достигающие завершения споры.

«Сквозные» черты культуры лишь как тенденции кристаллизуются в качестве таковых, при этом, естественно, не автоматически, а благодаря труду, творчеству, познавательной деятельности, гражданским инициативам субъектов. Вышеуказанное позволяет не считать оправданной идентификацию культуры по каким-то рукотворным составляющим общественного бытия, будь то надбиологические программы, коды, нормы, смыслополагание, образцы и т.п., ибо они могут вмещать в себя разрушительное, а не только созидательное начало. Так, образ камикадзе - один из тех социальных кодов, развертывание и претворение которого в соответствующее поведение едва ли можно отнести к культуре. А тщательно разрабатываемые ваххабитами программы по установлению их мирового господства и уничтожению «неверных» надо отнести к антикультуре. Да, культура нередко кодируется, но и антикультуру её вершители иногда свертывают в коды.

Реальную культуру составляют не только и не столько программы, сколько способность субъектов выполнить продуктивные программы, практический перевод людьми культурогенности в культуроносность. Культура должна идентифицироваться по определенным характеристикам её составляющих: культуроносны та деятельность и её результаты, которые соответствуют антропо- и обществофильному измерениям. Нравственная идея истинной человечности является верховной правительницей культуры, при этом актуализируется гегелевское понимание нравственности как снятого итога функционирования политики, права, экономики и индивидуальной моральности. На основе обладания такими признаками как качественность (соответственно разумным потребностям людей), созидательность, гуманистичность, культурогенная активность и её плодоносные результаты должны возводиться в ценности и заслуживать к себе отношение как к благотворным накоплениям.

Универсалии культуръ. Особенные и уникальные культуроносные формы тесно увязаны с универсальными культуроносными образованиями. Культура массивно представлена в обществе и её универсалии, на наш взгляд, не сводятся к мировоззренческо-гносеологическим категориям, хотя последние входят в ряд универсалий. Куниверсалиям культуры относятся родовые и крупновидовые, они же почти повсеместно распространенные на Земле формы циивлизованной общественной жизнедеятельности, а также общественного устройства: производство, труд, управление, поселения, познание, творчество, общественные отношения, нормы, наука, искусство, право, мораль, быт, спорт, игры и т.д. Но в качестве явлений ценностных родовые формы проступают лишь через их определенные антропо- и обществофильные видовые модификации, в то время как какие-то иные из видовых разновидностей универсалий наполняются антикультурным содержанием. Так, экономика может претворяться в такую негативную модификацию, как теневое предпринимательство; торговля может вестись в форме «дикого базара»; вещание через СМИ может служить социально вредному манипулированию сознанием масс; юридические законы могут быть драконовскими; искусство бывает и низкопробным; а что касается морали, то налицо не только общечеловеческая, но и мафиозная, фашистская и т.п. мораль. 


\section{Философия и культура 10(70) • 2013}

Прочитав вышенаписанное, не поставят ли мне читатели в укор унылость в обрисовке культуры, невнимательность к красочности её образований? Конечно, было бы наивностью игнорировать большое своеобразие и яркую выразительность проявлений культуры в условиях различных обществ всех времен. С.Н. Иконникова пишет, что «явления культуры ускользают от рационалистического анализа, не всегда поддаются точному описанию и объяснению. В них остаются неопределенность, недосказанность, загадочность и таинственность. Культура внутренне противоречива и трудно предсказуема» ${ }^{18}$. В основном надо согласиться с этими положениями, но они требуют комментариев. Явления культуры не всегда ускользают от рационалистического анализа и - бывает до поры до времени. В связи со своеобразием и причудливостью некоторых проявлений культуры имеются два варианта. Первый состоит в возможности «подтягивания» своеобразия под родовую или крупновидовую форму общественного бытия. Например, сколько бы ни были разнообразны танцы у разных народов, танцы - всегда искусство, они - его подвид и относятся к художественной культуре.

Второй вариант интересен наведением исследователя на процессы зарождения и становления новых родовых и крупновидовых общественных форм. Так, не одновременно с возникновением труда и материального производства появились писаное право, образование, социальная помощь и т.д. Развитие общественного бытия выражается, в частности, в постепенном вызревании в его условиях новых родовых и крупновидовых форм, которые нередко зарождаются в виде уникальных, поначалу трудно объяснимых явлений, т.е. в виде необычных «ростков». Диалектика учит о возможности перехода единичного в общее, хрестоматийный пример чего - это становление торговли как родовой формы общественного бытия на основе обретения устойчивого характера редкими и нерегулярными актами обмена благами между родами, что потом стало сопровождаться появлением денег, сначала устных правил обмена, а затем и юридического оформления деятельности торгующих сторон. Конечно, не любое единичное перерастает в общее, единичное, случайное и в природной, и в социальной среде не всегда приживается. 18 Иконникова С.Н. История культурологических теорий.
2-е изд. СПб., 2005. С. 19.
Признание культуроносности лишь определенных партикулярных модификаций родовых форм общественного бытия составляет одну из причин теоретической несостоятельности отождествления культуры с общественным организмом в целом. А веским основанием глобализации выступает сосредоточение в культуроносных видах родовых форм констант цивилизованного устройства и образа жизни, что означает отсутствие в основном несопоставимых друг с другом культур и общественных систем, сколь бы ни были своеобразны и даже затейливы видовые модификации родовых форм в различных регионах и разные времена. Уровень развития стран можно сравнивать и определять по степени окультуренности хозяйствования, управления, права, трудовых отношений, образования, здравоохранения и других универсальных цивилизационных образований.

Антикультура. Культуру нельзя постичь, не противопоставляя её антиподам. Среди них выделяются как хаотично осуществляемые, не имеющие отработанных способов и несущие деформации и разрушения человеческие действия в виде, скажем, вандализма или варварства, так и антикультура: по-своему мастерски возделываемые, отехнологиченные антисоциальные практики. Это могут быть хищническое выкачивание природных ресурсов, подпольная экономика, деспотические режимы, виртуозная коррупция, искусное манипулирование массовым сознанием, деятельность религиозных тоталитарных сект и прочее. Будучи прикрыта культурообразностью, антикультура нередко трудно распознается, часто не легко и не быстро выявляется её асоциальная направленность, зловредная роль, отсутствие у неё «человеческого лица». В конечном счёте ею подрываются устои общественного бытия. Отличать от культуры и выявлять антикультуру необходимо в целях обеспечения общественного благосостояния, хотя надо также принимать во внимание возможность наличия между культурой и антикультурой амбивалентных и переходных форм. Складывание не только культуры, но и антикультуры сопровождает общественную историю ${ }^{19}$, они в каких-то сферах общественной жизнедеятельности могут тесно переплетаться, что затрудняет борьбу с антикультурой.

Противоречие между культурой и антикультурой, на наш взгляд, составляет основное

\footnotetext{
19 Так, производство и накапливание средств массового уничтожения людей относится к антикультуре, но оно в своё время служило сдерживанию начала и развертывания третьей мировой войны.
} 


\section{Философия культуры}

противоречие цивилизации. Вершители антикультуры - это часто сильные и изворотливые противники субъектов культуры, умеющие в определенных случаях поставить себе на службу даже право, например, это делают рейдеры. Для сокрушения антикультуры требуются культурогенные ресурсы: юридические, политические, экономические, кадровые и др. средства, а также умения, воля и энергия со стороны субъектов позитивной активности. Обращение исследователями внимания на культуру при игнорировании антикультуры придает пониманию цивилизации весьма и весьма урезанный и упрощённый вид.

Закономерности складьвания и функционирования культуръ. Среди них назовем следующие: продуцирование, освоение, наследование ценностей, в основе чего лежит накопление и освоение человечеством социально-экзистенциального опыта с ходом истории; преемственность от одного этапа эволюции культуры к другому; установление определенных соотношений между природным и социальным, а также между личностным и общественным началами человеческой жизнедеятельности; вызревание субъектов и субъектных структур, способных к культурогенной активности; тесное взаимодействие и взаимокорректирование идеального и реального начал общественной жизни; складывание культуроносных практик в качестве главных показателей окультуривания человечества; осознанность субъектами антиподов культуры, разработка и применение способов пресекания антикультурной активности. Устойчивые социо-антропологические следствия относительно удачного функционирования культуры - утверждение человеческого достоинства в качестве онтологического атрибута людей и возделывание общественных отношений согласно гуманной социальной ориентированности - претерпевающие в настоящее время становление закономерности культуры. Чертой её утверждения в цивилизованных странах стало сопровождение материального и духовного производства страховочными и защитными - экологическими, правоохранительными, медицинскими, гражданскооборони-тельными, педагогическими и иными практиками.

К рассматриваемым закономерностям относится и то, что содержательное наполнение культуры требуется то и дело устанавливать, а её саму постоянно утверждать, если принимать во внимание относительность социальных оценок, смену эпохи, человеческих поколений, возвышение потребностей людей с ходом истории, появление новых человеческих творений. Имеется и структурный закон культуры: её строение в социильном филогенезе изоморфно созидательной человеческой активности. Соответственно в качестве элементов культуры предстают её субъекты; цели; прогнозы; идеалы; программы и регулятивы; знания; умения, навыки людей; культурогенная деятельность; культуроносная предметность; семиозис; оценки содеянного, произведенного и субъектов активности.

Заключение. Позитивная роль человека в мироздании состоит в его способности как субъекта культуры наращивать сущее, встраивать в природу иной по качеству - надприродный мир. Но если люди в конце концов окажутся неспособными обеспечить по преимуществу конструктивно-продуктивный характер их активности, то культура начнет свертываться, человечество гибнуть, и разве сущее тогда не претерпит убавления?

Философы не пишут конкретно-исторической картины состояния общественной жизни, а оно все еще полно, если иметь в виду отрицательное, конфликтности, агрессий, насилия, жестокости, человеческих страданий, преждевременных смертей и т.п. Любомудрие логически выявляет возможные в принципе и желаемые участниками общественных отношений преобразования в социуме, которые в определенном объеме претворяются в действительность в некоторых странах и в какой-то мере на мировой арене. В.М. Розин по праву усматривает «цель философа» в «осмыслении современности, создании мыслительного плацдарма для ответов на её вызовы. Это предполагает, с одной стороны, критику отживших ... способов мышления и видения, с другой стороны, создание новых идей и схем...; с третьей - разворачивание новых типов социальности и рефлексии. В этом смысле философия - не только познание, но и формы новой жизни» ${ }^{20}$. Философия культуры доводит до нас базовые принципы объяснения и производства ценностных форм общественного бытия.

При обосновании масштабных нововведений требуется опора как на данные конкретных исследований (социологических, технических, экономических, экологических, медицинских и др.), так и на философские положения о природе социума, общественных отношений, характере потребностей и активности людей, базовых принциипах окультуривания.

20 Розин В.М. Теория культуры. М., 2005. С. 152. 


\section{Философия и культура 10(70) • 2013}

\section{Список литературы:}

1. Выжлецов Г.П. Аксиология культуры. СПб, 1996.

2. Гуревич П.С. Философия культуры. М., 1995.

3. Запесоцкий А.С., Марков А.П. Становление культурологической парадигмы. СПб, 2007.

4. Лапина Т.С. Философия культуры: вариант понимания. М., 2003.

5. Ларин Ю.В. Онто-логика культуры. Тюмень, 2004.

6. Межуев В.М. Идея культуры. Очерки по философии культуры. М., 2006.

7. Неретина С., Огурцов А. Время культуры. СПб, 2000.

8. Розин В.М. Теория культуры. М., 2005.

9. Степин В.С. Цивилизация и культура. СПб, 2011.

10. Туровский М.Б. Философские основания культурологии. М., 1997.

11. Человек как субъект культуры. М., 2002.

12. Чумаков А.Н. Метафизика глобализации. Культурно-цивилизационный контекст. М., 2006.

\section{References (transliteration):}

1. Vyzhletsov G.P. Aksiologiya kul'tury. SPb, 1996.

2. Gurevich P.S. Filosofiya kul'tury. M., 1995.

3. Zapesotskii A.S., Markov A.P. Stanovlenie kul'turologicheskoi paradigmy. SPb, 2007.

4. Lapina T.S. Filosofiya kul'tury: variant ponimaniya. M., 2003.

5. Larin Yu.V. Onto-logika kul'tury. Tyumen', 2004.

6. Mezhuev V.M. Ideya kul'tury. Ocherki po filosofii kul'tury. M., 2006.

7. Neretina S., Ogurtsov A. Vremya kul'tury. SPb, 2000.

8. Rozin V.M. Teoriya kul'tury. M., 2005.

9. Stepin V.S. Tsivilizatsiya i kul'tura. SPb, 2011.

10. Turovskii M.B. Filosofskie osnovaniya kul'turologii. M., 1997.

11. Chelovek kak sub"ekt kul'tury. M., 2002.

12. Chumakov A.N. Metafizika globalizatsii. Kul'turno-tsivilizatsionnyi kontekst. M., 2006. 